\title{
ゴムの摩擦
}

内 山吉 隆*.ミシェル・バーキンス**

1. は じめに

15世紀にゴムの存在が西欧人に知られるようになった 後，18世紀にはアマゾンの優れたゴムの木が西欧に紹介 された1).

当時のイギリスの化学者Joseph Priestleyによってゴ ムで鉛筆の字を消すことが発見され，その当時india rubber と呼ばれ，これが後にゴム(rubber)の語源となっ た2)3)。その消しゴムは,ゴムの摩耗現象をたくみに利 用したものである. その後, 自動車用タイヤ, シールや ベルトなど，摩擦部分に広く使用されるようになった。

ゴムは金属やプラスチック材料に比べて弾性率が低 く, 伸びが大きい.このため接触面積が大きく, 高摩擦 を示す．また，ゴムの摩擦挙動には他の材料にはみられ ない興味ある現象がいくつかみられる．特に柔らかく滑 らかなゴム表面と滑らかな相手面との間ではすべり方向 に直角な分離波 (waves of detachment 又は Schallamach waves) が形成されることが知られている4). 更にその Schallamach waves の伝ぱの挙動は Barquins と Courtel ら5)6)によって光学的方法を用いて詳細に調べられてい る.ゴムの摩擦において, 凝着部の引きはがしがすべり 面とは垂直方向に起こるェレガントな現象であると同時
に, 摩擦中のエネルギーの消費が凝着部の引きはがしに よって主として起こっている7 9). 従来よりゴムの摩擦 の解説は, Conant と Liska ${ }^{10)}$, 山田 ${ }^{11)}$, Schallamach ${ }^{12)}$, Roberts $^{13)}$, Barquins ${ }^{14)}$, 内山占)らによって書かれている が, ここでは従来からの摩擦の研究経過を述べるととも に, 最近の摩擦と凝着とに関する研究について考察を行 った。

\section{2. 摩擦面の接触}

ゴムの摩擦を考えるに当たって，まず接触について述 ベる．金属のように塑性的な接触が起こるものでは，真 実接触面積 $A$ は荷重 $W$ に比例し, 平均降伏圧力 $p_{m}$ に 反比例して次式のように表わされる16).

$$
A=W / p_{m}
$$

しかし, ゴムで主として起こる弾性接触では荷重 $W$ で押しつけた半径 $R_{1}$ と $R_{2}$ の 2 つの球では, 接触円の 半径 $a$ は Hertzによれば次のように示される.

$$
a^{3}=\frac{3}{4} \pi\left(k_{1}+k_{2}\right) \frac{R_{1} R_{2}}{R_{1}+R_{2}} W
$$

ここで， $k_{1}$ と $k_{2}$ は各球の弾性に関係した定数であり， 次の関係がある.
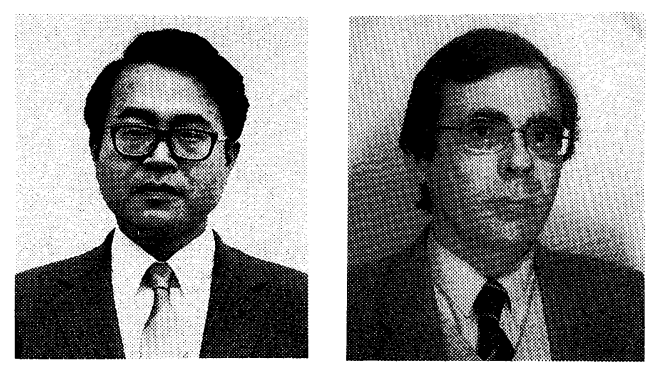

* 金沢大学工学部生産精密工学科 ( $\mathbf{\top} 920$ 石川県金沢市小立 野 2-40-20) 助教授. 工博. 昭和39年金沢大学工学部精密工 学科卒業. 昭和 40 年同大助手, 昭和 50 年同大助教授, 現在 に至る。〈専門〉トライボロジ(摩擦, 摩耗, 潤滑), 特に プラスチック及びゴムの摩擦・摩耗.

く越味〉旅行, 音楽, アマチュア無線(写真左)

** Equipe de Recherche de Mécanique des Surfaces du CNRS, Laboratorie Central des Ponts et Chaussées (58 Boulevard Lefebvre, 75732 Paris Cedex 15, France) Research Director, Head of the Surface Mechanis Laboratory, ETSL (High School of Technics Laboratory) 教授. Dr. of Science, CNAM (French National High School for Training Engineers) 卒業. <専門>表面の力学及び固体の接触. それらの弾性 体の凝着・摩擦・摩耗の研究への応用.

<趣味>音楽, 特に中世音楽 (写真右) 


$$
k_{1}=\frac{1-v_{1}^{2}}{\pi E_{1}}, \quad k_{2}=\frac{1-v_{2}^{2}}{\pi E_{2}}
$$

ここで， $v_{1}, v_{2}$ はそれぞれ材料のポアソン比， $E_{1}, E_{2}$ は 各材料のヤング率である. 接触面積 $A$ は $\pi a^{2}$ であり, $W$ 2 $/ 3$ 乗に比例し, 次のように書ける.

$$
A \propto W^{2 / 3}
$$

しかし，低荷重の接触では接触面積は Hertzによって 予想されたものより大きく，荷重を０（ゼロ）にしてもあ る一定の面積の接触が観察された，高荷重では接触面積 はHertzの理論にかなりよく従った．これは表面の吸引 力が固体面間に㗢き，そのため高荷重ではこの吸引力に よって付加される接触応力は考慮しなくてよいが，低荷 重では重要になることを示している17). Johnson ら ${ }^{17)} に$ よれば，表面エネルギー $\gamma\left(=\gamma_{1}+\gamma_{2}-\gamma_{12}\right)$ なる 2 物体間 に作用するみかけの応力 $W_{1}$ は, 負荷された応力 $W$ よ り大きく，次式で示される。

$$
W_{1}=W+3 \gamma \pi R+\sqrt{\left\{6 \gamma \pi R W+(3 \gamma \pi R)^{2}\right\}}
$$

ここで, $R=R_{1} R_{2} /\left(R_{1}+R_{2}\right)$ である.

表面エネルギー効果を考慮するように変形した Hertz の式は次のように示される.

$$
a_{1}^{3}=\frac{R}{K}\left(W+3 \gamma \pi R+\sqrt{\left\{6 \gamma \pi R W+(3 \gamma \pi R)^{2}\right\}}\right.
$$

ここで, $K=\frac{4}{3 \pi\left(k_{1}+k_{2}\right)}$ である.

$\gamma=0$ とすると単純な Hertz の式 $a^{3}=R W / K$ となる. 荷重が 0 (ゼロ) でもある接触面が作られ, 次式で与えら れる。

$$
a_{1}^{3}=R(6 \gamma \pi R) / K
$$

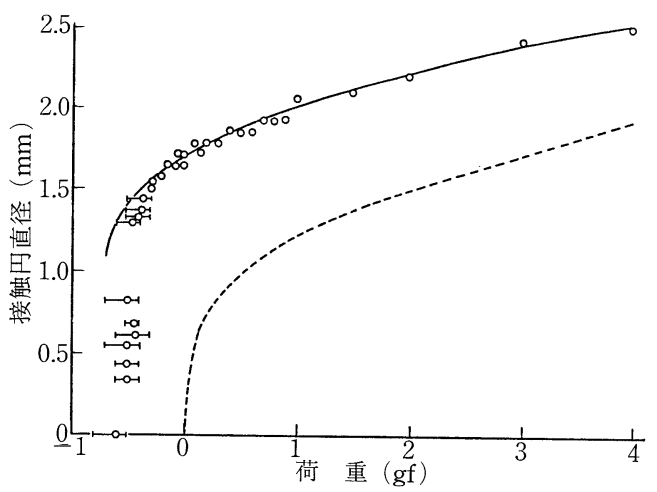

図 1 ゴム球 $(R=2.2 \mathrm{~cm})$ とゴム平板とが小さな正 及び負の荷重下で接触したときの接触円直 径17)

$\bigcirc:$ 接触の結果, $\cdots:$ Hertz の理論,

一：吸引力を考慮した理論
荷重が負，すなわち引きはなし力が加わると接触円半 径は減少し，ちょうど次式の負の力が加わったときに球 の引き離しが起こる。

$$
W=-\frac{3}{2} \gamma \pi R
$$

おもしろいことにこのとさの力は弾性率に無関係である ことである.

図 1 は半径 $2.2 \mathrm{~cm}$ のゴム球とゴム平板とを接触させ たときの接触面直径と荷重との関係を示したものであ り，-0.3 gf 以上の荷重で各ゴム表面のエネルギーを34 $\mathrm{erg} / \mathrm{cm}^{2}$ と仮定したとき式(5)によく一致することがわか る17). しかし，引きはがしの生じるところでは必ずしも よい一致を示さない，接触後の面積はある間は時間とと もに変化し，引きはがし力は時間依存性があり，理論と 必ずしも一致しなかったものと思われる ${ }^{17)}$. ここで生じ たゴム間の吸引力は主として van der Waals 力によるも のであり，水素結合や静電気力も作用するかもしれない． Johnson ら ${ }^{17)}$ の理論は凝着した接触部の平衡状態につい て求めたものである. その後, Maugis と Barquins ${ }^{18)}$ は 破壊力学の考えを用い, 動的な凝着部の分離について初 めて研究を行い, 一定荷重下で接触の不安定が生じるこ とについて理論的に解析した.

\section{3. 弾性体上のすべり摩擦}

粘弾性体上を硬い球が図 2 (a)のようにすべる場合につ いて考えてみる。接触は弾性接触であり，ほぼ摩擦力 $F$ は凝着力 $F_{\text {adh }}$ と, すべりや転がり中のヒステリシス損 失に伴ら変形の項 $F_{\text {def }}$ の和として表わされ, 次式のよう に書ける19).

$$
F=F_{\text {adh }}+F_{\text {def }}
$$

ここで $F_{\text {def }}$ は内部摩擦に関係するものであり, 図 $2(\mathrm{~b})$ に 示した純粋な転がり摩擦は変形した固体のヒステリシス

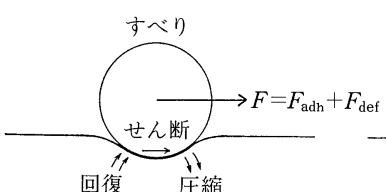

(a)

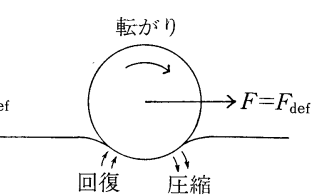

(b)
図 2 (a) 弾性体上の硬い球状スライダーのすべり 摩擦

摩擦力は, $F=F_{\text {adh }}+F_{\text {def }}$ と書ける。ここで $F_{\mathrm{adh}}$ は界面での凝着の項, $F_{\mathrm{def}}$ は固体中のヒ ステリシスによる変形損失の項である

(b) 凝着の項を無視してもよい場合の転がり 摩擦は変形損失の項による ${ }^{19)}$ 


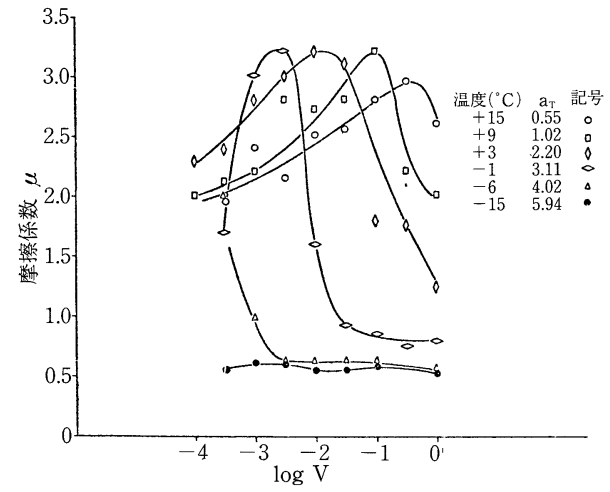

図 3 アクリロニトリルブタジェンゴムのきれいな 表面とガラス半球とのすべり摩擦 ${ }^{20)}$ (荷重50 gf)

損失によるものである ${ }^{19)}$.

以前に広範囲な温度, 速度で各種ゴムの摩擦が調べら れた。図 3 はアクリロニトリルブタジェンゴムとガラス 半球との摩擦を示したものである 20 . 広範囲な摩擦速度 において摩擦係数の各温度で変化する様子を示してい る.より高温に抌いて摩擦係数 $\mu$ と速度 $V$ との $\mu-V$ 曲 線が高速度側に移動するのが観察され, WLF 式を適用 して移動係数 $a_{T}$ は次のよらに表わされる.

$$
\log a_{T}=\frac{-8.86\left(T-T_{s}\right)}{\left(101.5+T-T_{s}\right)}
$$

ここで, $T_{s}$ はガラス転移点 $T_{g}$ より $50^{\circ} \mathrm{C}$ 高く, 次のよう な関係がある。

$$
T_{s}=T_{g}+50
$$

ここで摩擦係数を $\log \left(a_{T} V\right)$ に対して整理すると, 図 3 の結果は図 4 のよらに一本のマスターカーブに重ね合わ

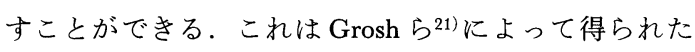
マスターカーブとよく一致している。しかし, Barquins と Roberts らの最近の報告22)によれば摩擦係数の 速度依存性はそれほど大さくなく, 低い $a_{T} V$ では摩擦 係数は 0.8 に減少し, Grosh ら 21$)$ の值よりかなり大きい ことがわかった。いずれにしても摩擦係数を温度及び摩 擦速度と結びつけて理解されている.

摩擦係数にピークができることの最も単純な説明は図 5 に示すように接触面積 $A$ とせん断強さ $S$ とが速度によ って変化し, 摩擦力 $F$ は $A$ と $S$ の積によって摩擦のピ ークができるというものである20).

しかし, あらい表中との摩擦では図 6 に示すように変 形損失と凝着損失との二つのピークを示すと考えられ る ${ }^{23)}$. より高温では摩擦係数の曲線は高速度側に移動す

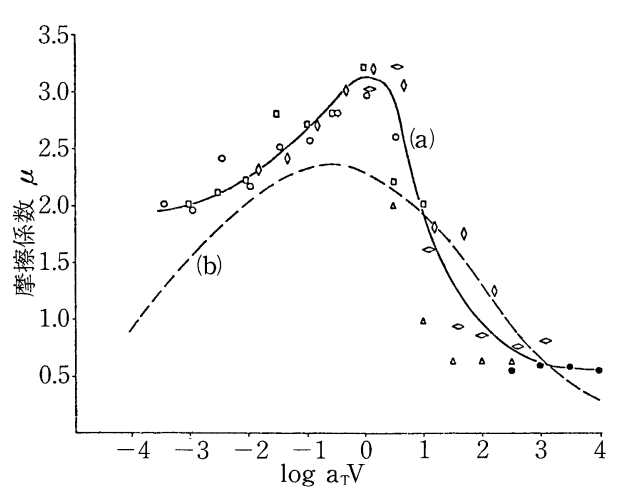

図 4 (a) 図 3 のデータをWLF 方式によって重ね 合せ，1本のマスターカーブを作ったもの

(b) 同じゴムを Grosch ら²1) とよって得られ た結果 ${ }^{20)}$

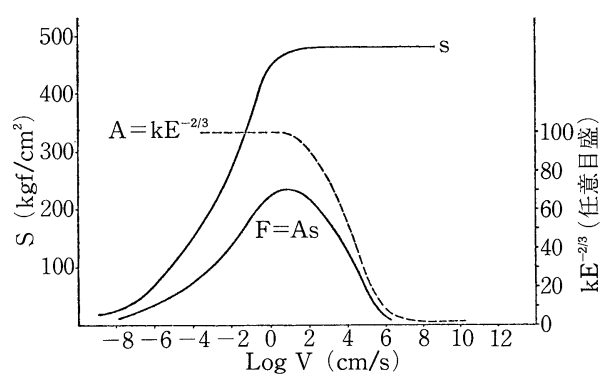

図 5 接触面積 $A$ とせん断強さ $s$ のすべり速度 $V$ による変化

せん断強さ $s$ は引張強さに等しいと仮定し, 接触面積 $A$ は $E^{-2 / 3}$ に比例すると仮定, $F=$ $A s^{20)}$ 
る.ゴムの摩擦の凝着の項のピークは粘弾性的性質をも とにしていると信じられている分子の動的なスティック スリップの作用に基づく多くの理論がある ${ }^{24)}$. 更に速度 とともに摩擦面の結合部の強さが増大寸るが，作られた 結合の数が速度とともに減少すると考光, ある摩擦速度 でピークができるといら Schallamach らの考えもある25). 他方，ヒステリシスのピークは各種ばねとダシュポット からなる機械的モデルを用いて示すことができる26).

\section{4. 凝着部の変形と摩擦-Schallamach waves}

柔らかな平滑なゴムが硬く滑らかな相手面とすべると き, Schallamach はゴムの相手面に対して相対的に移動 する方向に, 摩擦速度よりも速い速度で移動する分離波 を見い出した4)。図7(a)に示すようなゴム上を硬いスラ イダーがすべるとき, 又は図 7 (b)のように硬いトラック 上をゴムがすべるときを考觉る、ゴムは両方の場合に静 止していると考文, 摩擦力がゴムに生じる方向の接触端 を前側と定義する。この定義によれば分離波はいつる接 触面の前部から後部(ゴムのすべり方向)へ移動する. 図 7 中, $V$ は相対的なすべり速度, $w$ は分離波の伝ぱ方向 であり，Fはゴム上の摩擦力を示している4)。この波が 通過するときだけゴムが相手面に対して相対的に移動す る.しかし，その波が通過しない間はゴムと相手面との 凝着が保たれたままである。このことは相対的な变位は 接触面の全面で起こるのではなく, 分離波の移動によっ て起こり, Schallamach ${ }^{4)}$ は凝着部の破壊が従来考兄られ ていた接触面に平行ではなく, 波によってゴムが垂直に 持ち上げられて凝着部が破壊されることによって相対的 なゴムと相手面との変位が起こると考光た．Scha-
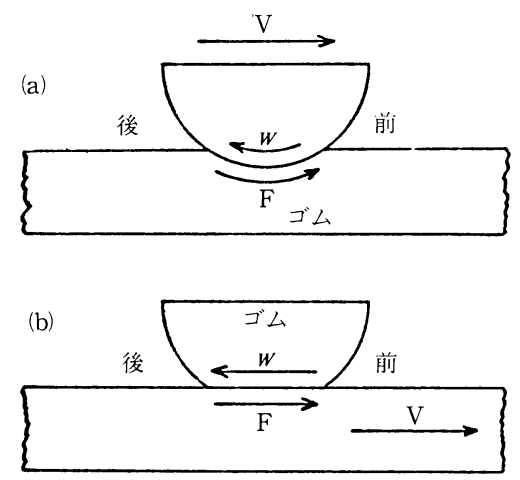

図 7 すべり速度 $V$, 波の伝ぱ $w$, 摩擦力 $F$ の方 向4)
(a) ゴムトラック上の硬いスライダー
(b) 硬いトラック上のゴムのスライダー

llamach waves の生成するときの摩擦速度や温度などの 条件や, その波の伝ぱ挙動について Barquins と Courtel ${ }^{6}$ は は詳細に報告している．その波の伝ぱを概念的 に図 8 の上うに示している。この現象の開始は弾性的な 効果 ${ }^{27}$ とよって支配されており, 接触部の入口部分の表

(a)

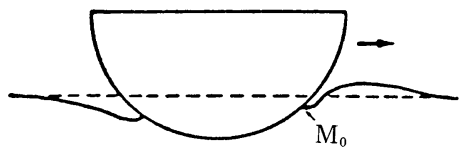

(b)

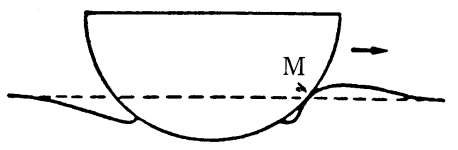

(c)

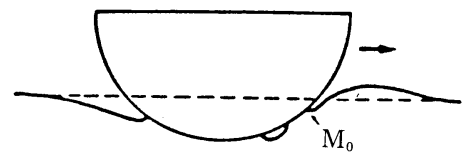

図 8 (a) (b) (c) Scchallamach waves の伝ぱの概念 図 $^{6)}$

すべり速度 $V>V_{c} \quad V_{c}$ : 臨界速度

(a)

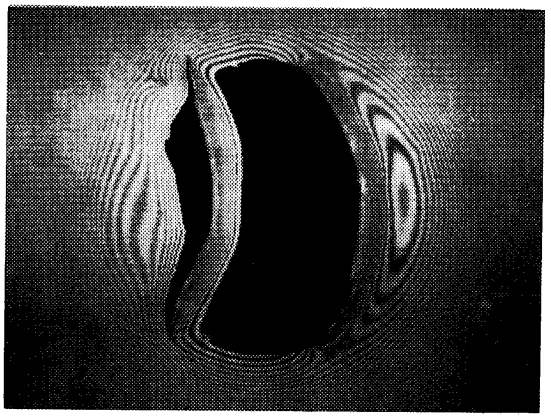

(b)

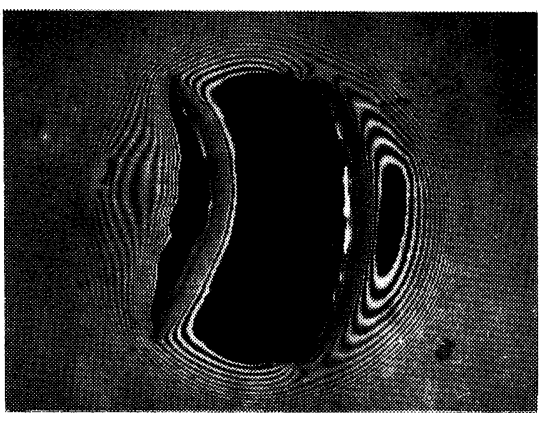

スライダー $\rightarrow$

$100 \mu \mathrm{m}$

図 9 (a)(b) Schallamach waves の生成を示す二 = ートンリング14) 
面の不安定さから生じるものである. 図 8 で粘弾性的な ふくれがスライダーのすべりによって生じ, 図8 (a)の接 触端 $M_{0}$ より前方の $M$ 点で付着する (図 $8(\mathrm{~b})$ ). その瞬 間にひだは溝となり，図８(c)に示すように分離波となっ て接触面を伝ぱし始める。これらの表面の形状は図 $9(\mathrm{a})$ (b)に示すニュートンリングのパターンから求められた ${ }^{14)}$. 付着ちょらど前にできる粘弾性的ふくらみは図 9 (a)k明 瞭にみられ, 一つの波がちょらど付着の後で図 $9(\mathrm{~b})$ に示 すように作られる。すべり速度が遅いときにはその溝は 長い距離伝ぱする前に空気を失ってしまい，二つの表面 の再凝着によって消失する ${ }^{6)}$.

波の伝ぱ中にゴムは最初に硬いスライダーの表面から 引きはがされ，その後再び付着する。そのため摩擦力 は，波の前部に拈ける引きはがし力と密接に関連してい るに違いない(7)8)28). 更に波の後部では再凝着して引き はがしに要したエネルギーを一部回復するが, 摩擦中の 大部分のエネルギーは波前部の引きはがし過程で消費さ れる。

Roberts ら7は，図10に示すよらなゴム板が硬いトラ ック上を速度 $V$ ですべるときに分離波が移動するとき の摩擦力と表面ェネルギーとの関係を説明している.

Schallamach waves が速度 $(\omega)$ で移動し，波と波の間隔 を入とする。トラックからゴムを引きはがすのに必要な 単位面積当たりの速度に依存する表面エネルギーを $\gamma$ と し，ゴム板の内部損失によるエネルギー散逸を無視すれ ば，定常摩擦ではエネルギーの損失は引きはぎによるも のであると考えられる. $d t$ の時間に力 $F$ は単位面積当 たり FV d t の仕事をし，波によって失われるェネルギー は $\left(\gamma_{w} / \lambda\right) d t$ である。したがって次の関係式が導き出さ れる7).

$$
F=\frac{\gamma_{w}}{\lambda V}
$$

この挙動はゴムの摩擦が粘弾性挙動と関係づけられる 興味ある機構である.なぜならば引きはぎの過程はすで

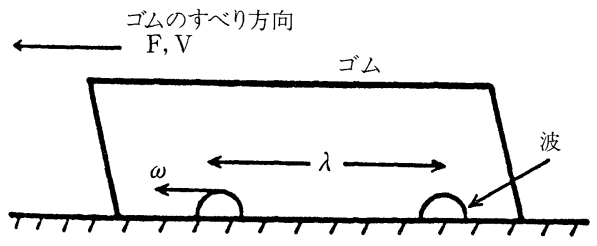

トラック

図10 硬いトラック上をゴムがすべる時の Schallamach waves $の$ 生成7)
に粘弾性的性格をもっていることが知られているからで ある、ここで摩擦力が引きはがしに要するエネルギーの みを考えたのは, 再凝着のエネルギーよりも引きはがし のエネルギーがかなり大きいからである.

Briggs と Briscoe ら ${ }^{8)}$ はゴムとガラス界面の凝着仕事 について報告している.もしゴムが清浄な表面に押しつ けられ，引きはがされるなら，二表面を分離するのに必 要な仕事は二面が接したとさに得たエネルギーよりも大 きいと考えた。これら二つのエネルギーの違いは，その 凝着と引きはがしのサイクル中に必要な仕事と等しく, それは凝着の仕事とみなされるものであった. 凝着の仕 事は接触面の端部の速度 (引きはがし速度)の関数であ り, 彼らの実験で得られた結果は, 凝着の仕事が引きは がし速度とともに増加を示した。

Briggsらは，また波がゴムとガラスとの界面を横切 り, 接触部が引きはがされ, その後再凝着するとき, 単

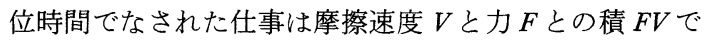
与えられ, これは接触面積 $A$, 凝着仕事 $\Gamma$ と波が表面を 横切る周波数 $f$ の積に等しく, 次式で示した.

$$
F V=A \Gamma f
$$

凝着の仕事は, 波の前部での表面の引きはぎの仕事と後 部で再凝着する仕事の差である. 式(11)を変形すると次の ようになる。

$$
\Gamma=F V / A f
$$

凝着仕事の Schallamach waves から直接計算されたもの と, ゴムとガラス界面の間の凝着仕事の直接測定の值と はよい相関を彼らは得た8). Briggsらの研究8) は先の Roberts $5^{7)}$ の研究を確かめるとともに更に拡張するも のである. Barquins ${ }^{28)}$ はすべり速度 $V$, 摩擦力 $F$ と波の 伝ぱ速度 $w$ との関係について調べた. $n$ の波が接触面を 直径 $l$ にある時間存在し, 各波の前で局部的な引きはぎ 力 $f_{p}$ が働くとさ, 次の関係を満足しなければならない。

$$
V F=n f_{p} w
$$

ポリウレタン上でのガラス球スライダーの実験では, 波の単位長さ当たりの力 $f_{p} / l$ は分離波の伝ぱ速度の0.6 乗に比例して変化することがわかった，その結果 $V F / n l$ は波の速度 の1.6乗に比例することが観察された。

Schallamach waves が生じるにはすべり速度, 荷重, 温度や摩擦面粗さなどの条件がある。

大変遅い速度では生ぜず, ある臨界速度 $V_{c}$ 以上で起 こる(29)30). 図11の $\log _{10} \mathrm{a}_{\mathrm{T}} \mathrm{V}=-1$ 付近で分離波が生じ る、それより大きなすべり速度では図11の $\mathrm{BB}^{\prime} \mathrm{CC}^{\prime}$ の 領域の垂直の線で示された幾分不規則な摩擦変動を示す 遷移領域がある ${ }^{6)}$.この領域では波の伝ぱは不安定であ 


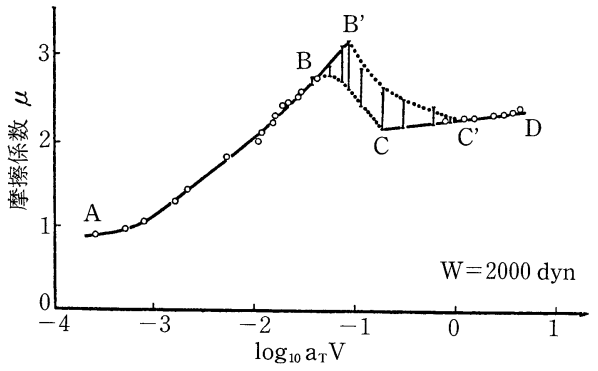

図11 摩擦係数のマスターカーブ

$\mathrm{BB}^{\prime} \mathrm{CC}^{\prime}$ の領域で Schallamach waves は作ら れるが，規則的には伝ぱしない6)

る.より速い領域 $\mathrm{C}^{\prime} \mathrm{D}$ では分離波の伝ぱは規則的とな り, 摩擦力は再び増加するが, ABの単純すべりの領域 よりも増加の勾配はゆるい。図11は各温度で得られた $\mu-V$ 曲線のマスターカーブを示すものであるが，重要な ことは，より高温では臨界速度 $V_{c}$ が高いことである.

更に興味あることは Barquins らが実験したガラス転位 点 $T_{g}$ が約ー $70^{\circ} \mathrm{C}$ の天然ゴムでは， $T_{g}+100^{\circ} \mathrm{C}$, すなわ ち約 $+30^{\circ} \mathrm{C}$ で分離波は消え, Williams-Landel-Ferry 式 （式(9)）の適応の限界を正確に示した. また。この温度以 上では摩擦曲線に摩擦の変動はみられなかった6).

内山 ${ }^{29)}$ は Barquins ら ${ }^{6)}$ よりもやや硬い $\left(H_{s} 30\right)$ 天然ゴ ムを用いて摩擦速度と荷重を変え, Schallamach waves の生成する領域を調べた. 摩擦速度による摩擦係数の変 化及び波の発生領域は彼ら5) と同様の結果であったが, 低荷重ではより低速度側から波が発生した。この低速か らの発生は低荷重における高摩擦係数と関係するものと 思われる29).

波の伝ぱ速度はゴム平板とガラスレンズとの組合せの とき, 人口部では比較的遅いが, 後部では急速に速くな り，すべり速度の数十倍に達することが Barquins らに よって示されている6). 内山ら 29)のすべり速度と荷重を 種々に変えた条件では, 波の伝ぱ速度がすべり速度及び 荷重とともに増大する結果が得られた。単位時間に発生 する波の数は低荷重では多く, 荷重の増大とともに低下 して一定值を示す傾向がみられ，また，すべり速度とと もに多くなる傾向がみられた（図12）.

柔らかく，平滑なゴムとレンズとの摩擦ではSchallamach waves の生成がみられたが，あらい表面では発 生はみられなかった ${ }^{29) 31)}$. 摩擦係数のすべり速度による 増加は $1 \mu \mathrm{m}$ 砥粒でバフしてあらした面においてもみら れ, そして高速では平滑なゴム面と摩擦係数の差はみら

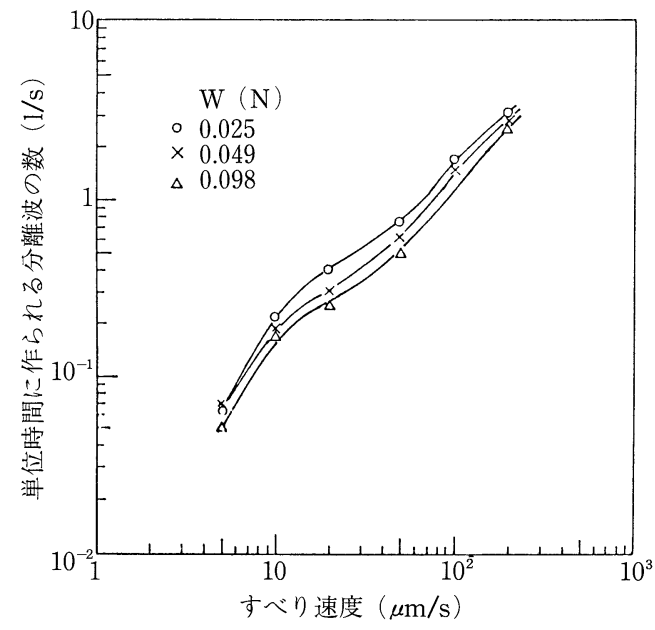

図12 単位時間に作成される分離波の数とすべり速 度の関係 ${ }^{29)}$

れなかった，低速では平滑な面のほらが摩擦係数が高 く, すべり速度の増加に伴い，ある臨界速度以上で平滑 な面との摩擦で波の発生がみられた。このような高い凝 着を示す面においては接触面全面での純粋なすべりが生 ぜず，Schallamach wavesの伝ぱによって，全面ですべ るよりも小さな摩擦力しか示さないものと思われる.

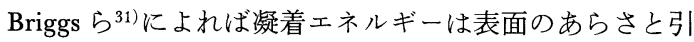
きはぎ速度に依存する，滑らかなシリコーン弾性体とあ らさをもつメタクリル樹脂の円筒を交叉させて接触さ せ，引き離す実験によって得た表面あらさと引き離し力 の関係の比較を行った．最初，あらさの増加は凝着を増 加させ，よりあらくなると著しい減少が硬いほうのゴム でみられる．他方，柔らかいゴムでは小さなあらさで極 大を明瞭に示さないこと除けば, Fuller と Taborの結果 に類似したものであった ${ }^{31)}$. どのよらな摩擦力のときに Schallamach waves が伝ぱするかについても Briggs と Briscoe $^{33)}$ は伝ぱするのに必要な界面の強さ $\tau_{0}$ が次のと きであると示している.

$$
\tau_{0}>\frac{1}{2 \pi \rho} \frac{G}{(1-v)}
$$

$v=1 / 2$ とすれば，上式は近似的に次のようになる.

$$
\tau_{0}>\frac{E}{7.5}>\frac{G}{2.5}, \rho=0.8
$$

ここで, $G, v$ と ン比と定数である．このようにある一定のせん断为以上 でないと波は伝ぱしない(33)37)。 
凝着は接触面の接触時間が長くなると増大する. Roberts ら ${ }^{34)}$ は滑らかなゴム表面とガラスの接触におい て，ブルーミングが激しいゴムでは始め凝着はみられな いが，長時間の接触で数けたも増加したことを確かめて いる。しかしきれいな表面では凝着はごく短時間で起こ る. 更にブルーミングは内部から表面へ絶えず各種の配 合物が浸み出してくるため，もし溶剤で表面をきれいに しても，数日後には表面はブルーミングされてしまうで あろう。このように表面の接触時間依存の原因はブルー ミングによるものであると考えられたが，長時間のブル 一ミングで何が起こっているかについては明確でなかっ た.しかし，ポリウレタンのよらなブルーミングのおき

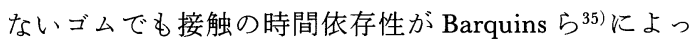
て確かめられたことから, 表面の突起に貯えられた弾性 的なェネルギーによっても影響を受け，時間とともに界 面の結合密度の増加もおきることがわかった，

Kendall ら99 角度で滑らかなガラス表面から引きはがされるとき，表 面間の転位(interfacial dislocation)，すなわち分離した 空隙が自然に形成されることを実証した。 これら分離部 分は引きはぎが進行するのを停止させる効果があり，し たがって凝着結合部の強さを増大させる. 理論的解析 は, 表面が離されたところの引きはがしと表面が自然に 付着する再凝着との組合せによってこのような分離部分 が生じ, 引きはがされた物体間の表面引力の結果として 結合部を再び作ることを示している. 更に自然に起こる 再凝着力は引きはがされた直後は最高であるが，ゴムが 空気にさらされる時間とともに減少し, 再凝着は分離部 分の生成や形状を決定することを彼らは報告している9.

このような分離は Schallamach waves ${ }^{4)}$ 高分子母材か ら充てんされた䋐維を引き抜くときや凝着結合部を引き はがし再凝着させるとさにもみられる

ガラス球と滑らかで柔らかいゴム表面とのすべりを伴 ら転り摩擦で, 球に駆動トルクが加わった加速状態のと き，接触面後半部に Schallamach waves がみられること を Barquins ら ${ }^{36)}$ は見い出した。しかし球にブレーキが かかる減速状態では波は生成されなかった。

最近 Barquins ら ${ }^{38)}$ 及び内山嘬) によって Schallamach waves が生成されるよりも遅いすべり速度で，接触面後 部で接触面が欠けたり, 回復したりする奇妙な現象が発 見された. 図13は接触面の引き伸ばされた後半部で再付 着するひだが作成されるメカニズムを Barquins らが模 式的に示したものである(14)38). 接線力が球状スライダー に加えられると接触面後半のゴム表面は分子引力の効果
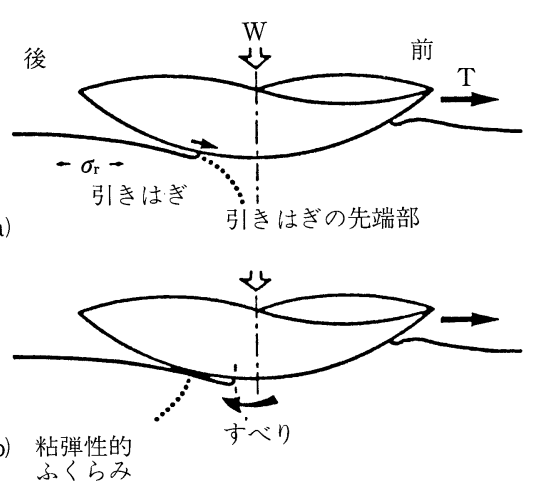

氺くらみ

(c)

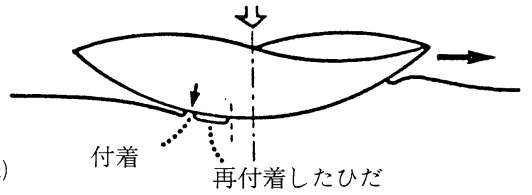

(d)

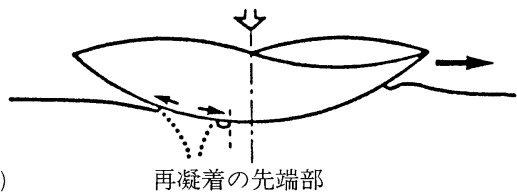

図13 大きな硬い球面スライダーとゴム表面との接 触面の引き伸ばされた後部で再付着したひだ の生成機構 ${ }^{38)}$

によって高引張り応力 $\sigma_{r}$ を受ける．スライダーの運動 のために応力が増加するとき，ゴムは後部で小さな角度 での引きはがし試験9)のときと同様に引きはがされる. そして接触部の後端は破面の先端とみなされ，図13(a)に 示すように接触の中心へ動く，そのとき，接触面がほと んど半円形になったとき突然すべりが後部で起こり，部 分的に極度の引張り応力を緩和する。 このすべりによっ て接触領域の後端より後方に瞬間的な粘弾性的なふくら みを作成する(図13(b))．ふくらみの高さは先の接触端の 後方でスライダー表面に瞬間的な付着を起こさせるのに 充分である，その結果，図13(c)で示すように一つの溝を 作る，そのとさ再凝着が観察される．再凝着は前後二方 向に向って進み，したがって溝は減少する(図13(d))。そ の後最初と同じ引きはぎ過程が繰り返し起こる ${ }^{38)}$.ここ で再付着したひだは接触する二面間の相対的な動きを与 えるものではない。しかし臨界速度以上で起こるSchallamach waves の機構とは対照的な現象である。この接 触部後部の周期的な变形は，主に分離波ができる臨界速 度 $V_{c}$ 以下にみられるが，臨界速度よりわずかに速い速 度で分離波が生成されるときにも同時にみられる。この 
ときには後部の変形の規模は比較的小さく, 接触面前部 から後部への分離波の通過によって後部のしわが延ばさ れ，分離した溝が消失して円に近い接触面となる ${ }^{29)}$.な お，このような後部変形が起きるときには大きな摩擦力 の変動を伴い, 接触面の後部が欠け, すべりが始まる直 前では最大の摩擦となる. 後部の付着がおき, 接触部後 部が回復してくるときには最低の摩擦を示す傾向がある.

\section{5. ゴムと水との摩擦}

ゴムと氷との摩擦は, 氷結路面でのタイヤの摩擦を検 討するためにも興味ある問題である. ゴムが低温での氷 とはよい凝着が得られるが，零度の融点近くになると凝 着が減り，摩擦は低下してしま 5 ${ }^{39) 40)}$. Roberts ら ${ }^{39)}$ は ゴムの球面スライダーと氷平板との摩擦を行い, 温度と 摩擦係数の関係を調べ, 同時に接触面の観察を行った。 図14は3つのすべり速度に扣いて得られた温度とみがい た氷との摩擦係数との関係を示したものである ${ }^{39)}$. 水の 上では摩擦係数は高速ほど高い值を示している．低温で の氷の摩擦係数はほぼ 2 であり, 摩擦係数は温度に依存 して各速度とも $-10^{\circ} \mathrm{C}$ 以上で值は急激に $1 / 20$ 以下に減 少した. 例えばー $1^{\circ} \mathrm{C}$ の $1 \mathrm{~mm} / \mathrm{s}$ 以下のすべり速度では, 摩擦係数は0.02にすぎず, 氷のトラックは融け, ゴムは 支持台であるガラスのターンテーブル上を水を介して同 じ速度ですべることになる。この時には摩擦係数は $0.8 \pm 0.2$ に上昇した. また水潤滑したときのガラス上の $10 \mathrm{~cm} / \mathrm{s}$ の速度で溶融点に近い氷とのような低摩擦が得 られた.このときには弾性流体潤滑の開始がニュートン の干涉色によって確かめられ, このとき摩擦は10 mm/ $\mathrm{s}$ 以上で急激に低下した. Roberts ら ${ }^{39)}$ の観察では $0{ }^{\circ} \mathrm{C}$

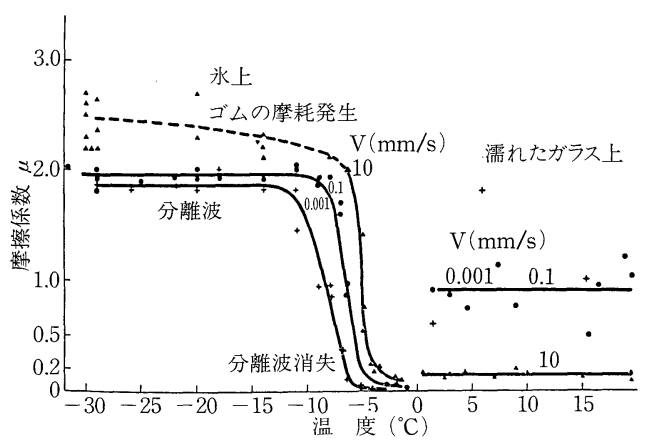

図14磨いた氷上及び需れたガラス上をゴム半球が すべるときの摩擦係数 ${ }^{39)}$

すべり速度：10 mm/s $(\mathbf{A}), 0.1 \mathrm{~mm} / \mathrm{s}(\mathbf{O})$ ， $0.001 \mathrm{~mm} / \mathrm{s}(+)$

荷 重: $0.22 \mathrm{kgf}$
付近で時どきみられる氷上に水が存在するとき，氷表面 では特別な現象がみられた。というのは皮の融点近くで はガラス上の水の場合より良い潤滑を示すことを示した.

更に表面観察によれば良く磨いたー $15^{\circ} \mathrm{C} よ り$ 冷たい 氷上で $1 \mathrm{~mm} / \mathrm{s}$ 以下の速度でゴム半球を摩擦したとき, Schallamach waves が接触部で見られた。 その形は規則 的な形をしており, 乾燥ガラスに摩擦したのと同様のも のであった。 また波がみられるときには氷上の摩擦は高 く，すべり速度に依存しなかった．波の伝ぱ中水上に対 しても乾燥ガラスと同様に引きはぎと凝着が起こった. このようにゴムと冷たい办との間では良い凝着が起こる ことを示している. $1 \mathrm{~mm} / \mathrm{s}$ 以上の速度又は $-15^{\circ} \mathrm{C}$ 以 下の温度では入り乱れた小波がみられる。 $-10^{\circ} \mathrm{C}$ 以上 では温度を上げると波は不明確になり, 波は小波に分解 する.より高温では波は最初の接触部の中央で, 後には 周辺部で伝ぱを中止した，そのとき一様な接触が得ら れ, 波のパターンは消失し, 摩擦は低下した. 波の消失 は温度と速度とに依存し, $-10^{\circ} \mathrm{C}$ 以上では $0.001 \mathrm{~mm} / \mathrm{s}$ で， $-7{ }^{\circ} \mathrm{C}$ 以上では $0.1 \mathrm{~mm} / \mathrm{s}$ で， $-5{ }^{\circ} \mathrm{C}$ 以上では 10 $\mathrm{mm} / \mathrm{s}$ でおこり, より高速度ではより高温で消失するこ とがわかった ${ }^{39)}$.

氷結道路上でのタイヤの摩擦は $-5{ }^{\circ} \mathrm{C}$ 以上の温度で は減少し, 自動車は危険な状態にさらされる。 そのため スパイクタイヤは有効であるが, 最近の道路の損傷と新 らたな粉塵公害の発生によって, スパイクタイヤの改良 が望まれている.

\section{6. おわりに}

ゴムの摩擦部を光学的に直接観察することによって, 摩擦面で起こる凝着と, そのすべりに伴ら破壊及びェネ ルギーの散逸過程が明らかになりつつある.

低荷重では滑らかなゴムでは接触面積は荷重の他に表 面の吸引力を考えねばならない．

ゴムの摩擦は温度とすべり速度に依存し，それらの間 には温度一速度の換算則 W.L.F 式が適応される。摩擦 は凝着部の摩擦と内部損失に基づく摩擦からなってい る. 滑らかで柔らかいゴムが滑らかな相手面と摩擦し, 凝着の項が重要な役割を占める場合には，エネルギーの 散逸は主として Schallamach waves による表面の引きは ぎ過程によって起こる。

Schallamach waves とは異なる接触部の後部変形が一 般には波が伝ぱするより低速でみられ，引きはぎと再凝 着が繰り返し起こり，このときには摩擦の変動を伴らも のであった。 
更に氷との摩擦における接触面の観察によって，氷上 に作られた水が急激に摩擦を低下させ, 弾性流体潤滑状 態になることが調べられ, 氷結道路におけるタイヤの摩 擦を考えるらえで，示唆に富む結果が得られている。

このような摩擦の研究は, タイヤ, シール, ワイパー ブレード，軸受にとって有益なものである.

\section{文献}

1）成沢慎一：日ゴム協誌，55,610（1982）

2）日本ゴム協会編：ゴム工業便覧，日本ゴム協会， 1531 (1979)

3）教育文化用品工業研究会編：教育文化用品工業便 覽，教育文化用品研究会，220（1950）

4) Schallamach, A.: Wear, 17, 301 (1971)

5) Barquins, M., Courtel, R., Thirion, P.: Wear, 27, 147 (1974)

6) Barquins M., Courtel, R.: Wear, 32, 133 (1975)

7) Roberts, A. D., Thomas, A. G.: Wear, 33, 45 (1975)

8) Briggs, G. A. D., Briscoe, B. J.: Wear, 35, 357 (1975)

9) Kendall, K.: J. Phys., D, 11, 1519 (1978)

10) Conant, F. S., Liska, J. W.: Rubber Chem. Techn., 33, 1218 (1960)

11）山田準吉：日ゴム協誌，38，868（1965）

12) Schallamach, A.: Rubber Chem. Techn., 41, 209 (1968)

13) Roberts, A. D.: Tribology, 9(2), 75 (1976)

14) Barquins, M.: Material Science and Engineering, 73, 45 (1985)

15）内山吉隆：第 2 回ゴム技術シンポジウム講演要旨 （ゴム工業技術員会報告 No. 8507）（昭和61年 2 月 26 日～27日，東京)p. 31

16）曽田範宗訳，バゥデン・ティバー：固体の摩擦と 潤滑，丸善 (1962) p.11

17) Johnson, K. L., Kendall K., Roberts, A. D.: Proc. Roy. Soc., London, A324, 301 (1971)
18) Maugis, D., Barquins, M.: J. Phys. D. 11, 1989 (1978)

19) Bowden, F. P., Tabor, D.: 'The Friction and Lubrication of Solids, Part II', Oxford, (1964) p.243

20) Ludema, K. C., Tabor, D.: Wear, 9 (5), 329 (1966)

21) Grosch, K. A.: Proc. Roy. Soc., A274(1), 21 (1963)

22) Barquins, M., Roberts, A. D.: J. Phys. D, 19, 547 (1986)

23) Moore, D. F.: Wear, 61, 273 (1980)

24) Moore, D. F.: 'The Friction and Lubrication of Elastomers, Pergamon Press', Oxford (1972)

25) Schallamach, A.: Wear, 6, 375 (1963)

26) Moore, D. F.: 'The Friction of Pneumatic Tyres', Elsevier, Amsterdam, (1975).

27) Gent, A. N.: Wear, 29, 111 (1974)

28) Barquins, M.: Wear, 91, 103 (1983)

29）内山吉隆：日ゴム協誌，58，319（1985)（日本潤滑 学会創立 25 周年記念東京大会 (昭和 55 年度研究発表 会)予稿集(1980年11月20日)p. 137)

30) Barquins, M., Courtel, R., Maugis, D.: Wear, 38, 385 (1976)

31) Briggs, G. A. D., Briscoe, B. J.: Wear, 57, 269 (1979)

32) Fuller, K. N. G., Tabor, D.: Proc. Roy. Soc. London, A345, 327 (1975)

33) Briggs, G. A. D., Briscoe, B. J.: Philosophical Magazine, A38 (4), 387 (1978)

34) Roberts, A. D., Othman, A. B.: Wear, 42, 119 (1977)

35) Barquins, M.: J. Adhesion, 14, 63 (1982)

36) Barquins, M., Maugis, D., Blouet, J., Courtel, R.: Wear, 51, 375 (1978)

37) Best, B., Meijers, P., Savkoor, A. R.: Wear, 65, 385 (1981)

38) Barquins, M.: Wear, 97, 111 (1984)

39) Roberts, A. D., Richardson, J. C.: Wear, 67 (1), 55 (1981)

40) Roberts, A. D.: Tribology, 14(1), 14 (1981) 